\title{
HIV POSITIF PADA PENDERITA TB PARU DI RSUD LABUANG BAJI KOTA MAKASSAR
}

\author{
Mujahidah Basarang ${ }^{1)}$, Andi Fatmawati ${ }^{1)}$, Zulkifli1 $^{1)}$ \\ ${ }^{1)}$ Akademi Analis Kesehatan Muhammadiyah Makassar \\ Alamat Korespondensi: peatoduri@yahoo.com
}

\begin{abstract}
Abstrak
Virus HIV menyerang sistem kekebalan tubuh dan menyebabkan AIDS. AIDS adalah kumpulan gejala atau penyakit yang disebabkan oleh menurunnya kekebalan tubuh akibat infeksi virus HIV seperti TB paru. TB paru merupakan penyakit infeksi yang mudah menular melalui udara yang disebabkan oleh Mycobacterium tuberculosis. Penderita TB paru dapat kebal terhadap obat salah satunya faktor Mikrobiologik, faktor klinik, faktor program,faktor AIDS-HIV dan faktor kuman. Penderita TB paru sering tidak menyadari dirinya bahwa selama hidupnya terinfeksi HIV. Tujuan penelitian adalah untuk mengetahui Gambaran Hasil Pemeriksaan Rapid test HIV Pada Penderita TB Paru Di RSUD Labuang Baji Kota Makassar. Penelitian ini bersifat observasi laboratorik pada jumlah sampel sebanyak 73 pasien. Darah penderita TB paru diperiksa HIV-nya dengan metode Immunokromatografi dan menggunakan Rapid test HIV. Hasil penelitian menunjukkan bahwa HIV Non Reaktif sebanyak 60 orang (82,2\%) dan HIV Reaktif sebanyak 13 orang (17,8\%) pada penderita TB paru di RSUD Labuang Baji Kota Makassar. Disarankan bagi penderita TB paru yang terinfeksi HIV diharapkan mengkomsumsi mineral ZN dan Vitamin, Masyarakat diharapkan menjaga pola hidup sehat, menghindari penggunaan jarum suntik yang tidak steril, hubungan seksual secara bebas dalam pencegahan virus HIV, Diharapkan kepada pemerintah untuk membangun panti khusus untuk menampung orang-orang yang terinfeksi HIV agar mampu menangani penyebaran virus HIV, Bagi peneliti selanjutnya disarankan untuk melakukan penelitian terhadap penderita TB paru dengan parameter yang lain.

Kata Kunci: Rapid test HIV, Penderita TB paru
\end{abstract}

\section{PENDAHULUAN}

HIV (Human immunodeficiency virus) adalah suatu virus yang dapat menyebabkan penyakit (AIDS). Virus ini menyerang sistem kekebalan tubuh, sehingga tubuh menjadi lemah dalam melawan infeksi. Dengan kata lain, kehadiran virus ini dalam tubuh akan menyebabkan defisiensi (kekurangan) sistem imun (Misnadiarly, 2014).

AIDS (Acquired immune deviciency sindrome) merupakan salah satu jenis penyakit yang paling menakutkan hingga saat ini. Penyakit ini bukanlah penyakit yang terdiri dari penyakit jenis tertentu, melainkan merupakan penyakit yang secara langsung menyerang sistem kekebalan tubuh (antibodi) manusia sehingga berbagai macam penyakit bisa dengan mudahnya masuk ke dalam tubuh manusia karena hilangnya zat antibodi (Irianto, 2014).

Penyakit yang mudah masuk melalui sistem pernapasan adalah bakteri Mycobacterium tuberculosis dapat menyebabkan penyakit TB paru.
Tuberkulosis sangat berpengaruh terhadap masyarakat karena penyakit tuberkulosis merupakan penyakit infeksi yang mudah menular. Penularannya melalui perantaraan ludah atau dahak penderita yang mengandung basil tuberkulosis paru. Pada waktu penderita batuk droplet yang terhirup oleh orang sehat masuk kedalam paru-paru yang kemudian menyebabkan penyakit tuberkulosis paru (Hiswani, 2014).

Setiap tahun dilaporkan sekitar 1,7 juta orang yang meninggal dunia akibat penyakit tuberculosis (Irianto, 2014). Penyakit tuberkulosis (TB) merupakan salah satu penyakit infeksi utama yang masih belum dapat dituntaskan secara global. Prevalensi tertinggi penyakit tuberkulosis dan peningkatan keadaan resistensi obat terutama ditemukan di negara-negara yang sumber dayanya terbatas dan tidak mampu menerapkan berbagai metode modern pemberantasan epidemik tuberkulosis. Penyakit ini bahkan memburuk di beberapa tempat di dunia terutama disebabkan adanya 
hubungan antara penyakit tuberkulosis dan peningkatan prevalensi resistensi obat dan berbagai epidemik infeksi HIV maupun AIDS (Irianto, 2014).

Tuberkulosis dan infeksi Human immunodifeciency virus diketahui mempunyai korelasi yang erat. Lebih dari $60 \%$ orang yang menderita HIV ternyata menderita TB masa hidupnya. Bahkan tuberkulosis merupakan penyebab utama dari morbiditas dan mortalitas orangorang penderita Human immunodifeciency virus. Pada pasien TB paru dengan Human immunodeficiency virus $\mathrm{HIV}$ ) positif menunjukkan tambahan kematian $0,45 \quad-0.62$ juta. Apabila seseorang positif HIV/AIDS maka sistem pertahanan tubuh akan menurun dan mudah terpapar penyakit TB paru maupun infeksi oportunistik. Adanya hubungan antara penderita TB paru dengan HIV positif merupakan penyebab utama terjadinya penyakit dan kematian serta prevalensi resisten obat (Pamungkasari, 2011).

\section{METODE PENELITIAN}

\section{Alat dan Bahan}

Alat yang digunakan pada penelitian ini adalah strip HIV, pipet tetes, tabung reaksi, rak tabung, sentrifuge, turiquet, holder, jarum, tabung vacum, dan stopwatch.

Bahan yang digunakan pada penelitian ini adalah sampel serum, larutan dilution buffer, kapas alkohol 70\% dan plaster.

\section{Prosedur Kerja}

Persiapan sampel

Sampel darah sebanyak $3 \mathrm{ml} \mathrm{di}$ dalam tabung disentrifuge dengan kecepatan $3000 \mathrm{rpm}$ selama 10 menit. Cairan paling atas berwarna kuning diambil sebagai sampel serum.

Pemeriksaan sampel menggunakan immunokromatografi

Sampel serum sebanyak 3 tetes diteteskan pada strip HIV. Larutan buffer diteteskan sampel serum pada strip. Strip didiamkan selama 20 menit. Sampel yang diteteskan pada ruang membran bereaksi dengan partikel yang telah dilapisi dengan protein A yang terdapat pada bantalan spesimen. Selanjutnya akan bergerak secara kromatografi dan bereaksi dengan antigen HIV rekombinan yang terdapat pada garis test.

\section{Interpretasi hasil}

- Positif (Reaktif) : terbentuk 2 atau 3 garis berwarna, satu pada zona garis test 1 atau 2 dan 1 pada zona garis control. Hal ini berarti pada serum terdapat antibodi HIV.

- Negatif (Non Reaktif): terbentuk satu garis warna pada zona garis control saja, ini berarti pada serum atau plasma darah tidak ada antibodi HIV.

- Tidak terbaca (Invalid): jika tidak timbul garis warna pada zona kontrol maka tes dinyatakan gagal, ulangi test dengan alat yang baru.

\section{HASIL DAN PEMBAHASAN}

Hasil pemeriksaan rapid test HIV pada 73 pasien penderita TB paru di RSUD Labuang Baji pada bulan Januari sampai Mei 2016 diperolah hasil pada tabel 1 .

Tabel 1. Hasil pemeriksaan rapid test HIV pada penderita TB paru RSUD Labuang Baji

\begin{tabular}{cc}
\hline \multirow{2}{*}{ Hasil Pemeriksaan } & $\begin{array}{c}\text { Jumlah penderita } \\
\text { TB }\end{array}$ \\
\hline Positif HIV & $13(17.81 \%)$ \\
Negatif HIV & $60(82.19 \%$ \\
Jumlah & 73 \\
\hline Hasil penelitian & menunjukkan
\end{tabular}
bahwa dari 73 orang penderita TB paru di RSUD Labuang Baji Makassar ditemukan $13(17.81 \%)$ orang pasien positif HIV dan $60(82.19 \%)$ orang pasien.

\section{PEMBAHASAN}

Berdasarkan Penelitian yang dilakukan secara observasi laboratorik, penelitian yang bertujuan untuk mengetahui gambaran hasil pemeriksaan rapid test hiv pada penderita TB paru di RSUD Labuang Baji kota Makassar.

Darah atau serum penderita TB paru didapatkan kemudian dilakukan pemeriksaan menggunakan alat SD HIV$1 / 2$. Pemeriksaan ini berlangsung di laksanakan di Laboratorium Patologi Klinik yang menggunakan metode 
Immunokromatografi, membuka pembungkus strip test dan meneteskan serum pada sumur sampel dan ditambahkan dengan larutan dilution buffer, HIV Reaktif menandakan garis test 1 atau 2 dan control berwarna pink sedangkan HIV Non reaktif tidak terdapat garis merah pada garis test 1 atau 2 tapi garis control berwarna pink.

Pemeriksaan HIV pada penderita TB paru dengan menggunakan metode Immunokromatografi menggunakan alat SD HIV-1/2, didapatkan hasil penelitian yang dilakukan dengan jumlah sampel sebanyak 73 orang pada penderita TB paru, jumlah HIV Reaktif sebanyak 13 orang $(17,8 \%)$ sedangkan HIV Non Reaktif sebanyak 60 orang $(82,2 \%)$.

Penderita TB paru adalah penyakit infeksi yang mudah menular melalui udara kemudian masuk kedalam sistem pernafasan yang disebabkan oleh bakteri Mycobacterium tuberculosis. TB paru akan resisten terhadap obat diakibatkan oleh adanya koinfeksi virus Human immunodeficiency virus (HIV). Penderita yang terinfeksi Virus HIV mengalami penurunan sistem kekebalan tubuh sehingga memudahkan masuknya bakteri Mycobacterium tuberculosis kedalam tubuh yang menyebabkan penyakit TB paru.

Penderita TB paru yang mengalami HIV Reaktif disebabkan darahnya mengandung virus HIV dan penderita HIV dapat terjangkit penyakit lain setelah 3 tahun sebagai tahap awal dari AIDS dan menyebabkan sistem kekebalan tubuh penderita TB paru menurun dan bahkan sulit untuk diobati dengan menggunakan obat tetapi dapat diperlambat perjalanan virus HIV dengan mengkomsumsi mineral zn dan vitamin yang bertujuan untuk meningkatkan metabolism pertahanan tubuh.

Faktor penyebab terjadinya HIV pada penderita TB paru yaitu:

1) Hubungan seksual yang beresiko dapat menularkan HIV karena didalam cairan genital (sperma dan lendir vagina) memiliki jumlah virus yang tinggi dan cukup banyak untuk memungkinkan penularan. Virus ditransmisikan melalui paparan mukosa oral, rektal, atau vagina selama kontak seksual. Terdapat hubungan penularan HIV melalui hubungan seksual kelamin- anus. Hal ini terjadi karena, mukosa rektum tipis dan mudah terjadi luka sehingga mengakibatkan adanya kontaminasi sperma yang mengandung virus HIV dengan luka pada mukosa rektum. Penularan HIV juga terjadi pada hubungan seksual kelamin-kelamin. Walaupun mukosa vagina lebih tebal, namun juga dapat terjadi luka yang akan terkontaminasi oleh sperma yang mengandung HIV.

2) Darah. Penularan melalui darah dapat terjadi melalui transfusi darah dan produknya, perilaku menyuntik yang tidak aman pada pengguna napza suntik, serta transpalasi organ yang tercemar virus HIV juga dapat menularkan.

3) Penularan ibu ke bayi. Infeksi HIV dapat ditularkan dari ibu ke janinnya pada saat hamil, persalinan, ataupun ASI. Kemungkinan penularan dari ibu ke janin adalah15-25\% pada Negara maju dan 25-35\% pada Negara berkembang. Penularannya melalui ASI (Air Susu Ibu) memiliki presentase sebesar $12-14 \%$ bila ibu telah terinfeksi.

Penderita HIV dapat terjangkit penyakit lain setelah 3 tahun sebagai tahap awal dari AIDS. Penderita AIDS dapat mengalami infeksi oportunistik karena pederita AIDS mengalami penurunan sistem kekebalan tubuh dan tidak dapat diobati jadi memudahkan masuknya bakteri-bakteri yang dapat menyebebkan peyakit lain dalam tubuh. Setelah terinfeksi HIV selama 13 tahun menunjukkan gejala AIDS dan kemudian mati. Tapi untuk memperlambat dampak dari penyakit AIDS dengan perbaikan asupan mineral $\mathrm{Zn}$ dan vitamin yang dapat membantu memperkuat dan meningkatkan fungsi sistem imun manusia.

Penderita TB paru yang HIV non reaktif menandakan penderita tidak terinfeksi HIV sebelum timbulnya 
penyakit TB paru. Saluran masuk Mycobacterium tuberculosis kedalam tubuh adalah saluran pernafasan, saluran pencernaan (GI), dan luka terbuka pada kulit. Kebanyakan infeksi TB terjadi melalui udara, yaitu melalui inhalasi droplet yang mengandung bakteri basil tuberkel yang berasal dari yang terinfeksi. Penyakit dapat menyebar melalui getah bening atau pembuluh darah. Organisme yang lolos dari kelenjar getah bening akan mencapai aliran darah dalam jumlah kecil, yang kadang-kadang dapat menimbulkan lesi pada berbagai organ lain (Sylvia et al, 2013).

\section{KESIMPULAN}

Berdasarkan hasil peneitian, maka disimpulkan bahwa jumlah penderita HIV Reaktif (+) sebanyak 13 orang $(17,8 \%)$ sedangkan HIV Non Reaktif (-) sebanyak 60 orang $(82,2 \%)$ pada penderita TB paru yang dilakukan penelitian di RSUD Labuang Baji Kota Makassar.

\section{DAFTAR PUSTAKA}

Anonim. 2011. Peran Mahasiswa Kedokteran Dalam Menyikapi Kejadian Tuberculosis diIndonesia (Skripsi).Makassar: Universitasa Muslim Indonesia. wilayah4.

Edyana. D. 2012. Diagnosis Serologis Infeksi HIV. Jakarta: Universitas Kristen Indonesia.

Ellya, et al. 2010. Buku Saku Metodologi Penelitian. Jakarta: TIM.

Hiswani. 2014. Tuberculosis Merupakan Penyakit Infeksi Yang Masih Menjadi Masalah Kesehatan Masyarakat. Medan: Universitas Sumatera Utara.

Irianto, K. 2013. Mikrobiologi Menguak Dunia Mikroorganisme. Bandung: CV. Yarama Widya.

Irianto, K. 2014. Bakteriologi Medis, Mikologi Medis dan Virologi Medis. Bandung: CV.Alfabeta.

Melnick, et al. 2005. Mikrobiologi Kedokteran. Jakarta: Salemba Medika.

Jawetz, et al. 2013. Mikrobiologi Kedokteran. Jakarta: Penerbit Buku Kedokteran EGC.

Lyndon, S. dan Luviana. E. D. 2010. Anatomi dan Fisiologi Untuk
Perawat dan Paramedis. Tanggerang Selatan: Bina Rupa Aksara.

Misnadiarly, D. H. 2014. Jakarta: Mikrobilogi Untuk Klinik Dan Laboratorium. Rineka Cipta.

Pamungkasari. E. P, et al. 2011. Kesediaan Pasien Tuberculosis Melakukan Tes HIV Pada Program Propida Initiated Testing And Counseling ( PITC ). J Respir indo (online): vol. 31, no. 3 .

Sylvia. A, et al. 2013. Konsep Klinis Proses-Proses Penyakit. Jakarta: Penerbit Buku Kedokteran EGC.

Radji, M. 2009. Buku Ajar Mikrobiologi Panduan Mahisiswa Farmasi dan Kedokteran. Jakarta: Penerbit Buku Kedokteran EGC. 
